\title{
Cold Warriors: Advancing the Library Modernizing Model in Latin America
}

\author{
Héctor J. Maymí-Sugrañes ${ }^{\star}$
}

Artículo recibido:

12 de junio de 2014.

Artículo aceptado:

11 de marzo de 2016.

\section{Abstract}

After War World II, modernization theories became fashionable as American business, political, and cultural elites, exercising unprecedented influence throughout the world, once again came to believe in the positivist notions of progress and civilization. The "modern" model rapidly gained wide support in both advanced capitalist and developing countries; and soon it was trumpeted as the best solution for less developed nations. Many of the initiatives undertaken and ideas tested in previous decades concerning cultural development culminated with the actions and programs taken on behalf of Latin Americans under the mantle of the Point IV Program and the Alliance for

* Centro de Enseñanza Técnica y Superior (CETYS Universidad), México. sugranes33@hotmail.com

INVESTIGACIÓN BiBLIOTECOLÓGICA, Vol.31, Núm.72, mayo/agosto, 2017, México, ISSN: 2448-8321. pp. 183-207 
Progress. The challenge was how to translate that model into a different reality. It did not completely work there, and in failing to do so, it diminished the effectiveness of many initiatives carried out under the auspices of InterAmerican relations.

Keywords: Modernization; Point IV Program; Alliance for Progress; Inter-American Relations.

\section{RESUMEN}

Los guerreros de la Guerra Fría: avanzando el modelo de modernización en las bibliotecas de Latinoamérica Héctor J. Maymi-Sugrañes

Luego de terminada la Segunda Guerra Mundial, las teorías sobre modernización se pusieron de moda principalmente porque las empresas norteamericanas, junto a las elites políticas y culturales, ejercían una influencia sin precedente a través del mundo. De nuevo se creyó en las nociones positivistas de progreso y civilización. El modelo "moderno" rápidamente gozó de apoyo tanto en los países avanzados capitalistas como en los países en vías de desarrollo. Pronto serían planteadas como las mejores soluciones para las naciones en vías de desarrollo muchas de las iniciativas e ideas establecidas en décadas previas concernientes al desarrollo cultural, que culminaron como acciones y programas llevados a cabo a nombre de los latinoamericanos bajo el manto del Programa de Punto IV y la Alianza para el Progreso. El reto fue cómo traducir este tipo de modelo de desarrollo en una realidad diferente. No funcionó de forma completa en Latinoamérica, haciendo inefectivas muchas de las iniciativas de las relaciones interamericanas.

Palabras clave: Modernización; Programa de Punto IV; Alianza para el Progreso; Relaciones InterAmericanas. 


\section{INTRODUCTION}

Truman's foreign-policy initiatives laid the foundation for a policy of containment, Cold Warriors, and military interventions in the name of freedoms for the next forty years.

The end of World War II did not bring peace. On the contrary, the winning powers immediately developed post-War strategies to exercise influence in different parts of the world. The United States (U.S.) and the Soviet Union (USSR) initiated a competition to determine who could be the most influential nation in the world. These two nations were the two superpowers after War World II, and represented two conflicting ideologies. The ideological and geopolitical battle between these two nations for worldwide influence and supremacy get the name of Cold War.

At the end of World War II, and in the wake of all the deprivation they suffered during the War's duration, the Latin American people harbored great hopes for the future. American and Latin American elites also had great hopes that after the War a period of peace and prosperity would cover the whole world, inspired by Western ideas of modernization and development. However, in the postwar years, the ideological confrontation began and the socio-economic, political, and cultural conditions of Latin America did not immediately improve.

Historically, the United States promoted modernization as a model for Latin American nations. The kind of modernization process that happened in the U.S. through capitalist-democratic development was the principal "model" to be followed in Latin America. That "modern" model rapidly influenced Inter-American relations and became part of the library activities undertaken by many organizations (from government, private sector, and non-governmental organizations).

For this paper, the primary objective is to understand the ideologies and their manifestations in library initiatives promoted by the Point IV Program and the Alliance for Progress to Latin America as part of the Cold War. For this reason, this paper has three areas. The first part is the Point IV Program and its library initiatives related to Latin America. Then the library initiatives taking place as part of the Alliance for Progress. At the end is a general comment by the consequences of ideology and cultural initiatives in Latin American development. However, in the middle of the Cold War, the Point IV promoted these initiatives as part of the "modern" cultural model. 
The Truman Doctrine in 1947 of containment of communist forces across the planet was an important foreign policy statement that affected relations between the U.S. and developing countries throughout the 1950s. The Truman Doctrine established the U.S. as a world police. These first years of the Cold War witnessed an ideological battle on a variety of fronts: economic, political, social, and cultural. To promote the values of the American democratic-capitalist system and assist in its implementation, President Truman noted in his inaugural address in 1949:

Fourth, we must embark on a bold new program for making the benefits of our science advances and industrial progress available for the improvement and growth of underdeveloped areas. [...] The United States is pre-eminent among nations in the development of industrial and scientific techniques. The material resources which we can afford to use for assistance of other people are limited. But our imponderable resources in technical knowledge are constantly growing and inexhaustible. I believe that we should make available to peace-lowing peoples the benefits of our store of technical knowledge in order to help them realize their aspirations for a better life. (Truman, 1979: 114)

Not only did the U.S. government worry about the socio-economic, political, and cul tural conditions of less developed countries, American non-governmental organizations (NGOs) such as the Rockefeller Foundation, worried about it as well. An analysis made by the Public Affairs Institute in a report made by the Rockefeller Foundation in March 1951 said:

The Rockefeller Board's report starts with the proposition that "strengthening the economies of the underdeveloped regions and an improvement in their living levels must be considered a vital part of our own defense mobilization." Much of its subsequent emphasis and recommendations goes toward emphasizing the needs and values of foreign aid, and justifying our aid in terms of our defense needs. This approach may be accepted as an expedient one which will appeal to the present majority of Congress. (Public Affairs Institute, 1951: 1)

The Rockefeller Foundation had the position that foreign aid to less developed nations was in U.S. national interest. With this position, the Foundation determined to increase foreign aid. Although, the U.S. Congress was reluctant to pass the 1950 Foreign Economic Assistance Act due to the prevalence of post-war isolationist feelings. Once the Act was approved, the Point IV Program gained the support of American NGOs as well as a significant 
portion of the private sector, the involvement and support of which played a significant role in the development of the Point IV Program.

The Point IV Program included provisions for cultural (library) development and technical cooperation and assistance. Specifically, American books and library techniques were to be key parts of the Point IV initiatives in the area of culture. The McGraw-Hill Company worked with the Point IV Program in promoting American books in less developed countries. In a booklet produced by McGraw-Hill International, entitled Books and Magazines in the Point Four Program, the role of published materials in technical cooperation and assistance projects was conceptualized:

The United States is at present training large numbers of foreign students in all fields of technology, bringing them to this country at considerable cost and effort. But this cost and effort necessarily limit the numbers who can be brought here for advanced education. A practical suggestion is that the same books which these students studied in the United States be sent to their native lands, thus multiplying the scores who have been brought here into thousands who can be instructed in their native countries. [...] For many practical and important reasons, therefore, American scientific and technical literature must be given a major role in the Point Four Program for aid to underdeveloped areas. This may be accomplished only through the allotment of Point Four funds for the purchase of books and magazines and for their distribution to the areas where they are so badly needed. These books and magazines, whose dollar cost is negligible and yet whose lasting value and effectiveness are immeasurable, are the indispensable basis for a successful Technical Assistance Program; they are tools of freedom and emissaries of democracy. (McGraw-Hill International, n. d.)

For the McGraw-Hill Company, books and magazines were very important components of the ideological battle that Point IV wanted to wage against the perceived communist threat in less developed countries; people, books and magazines were a form of long-term insurance that the technical cooperation and assistance would have a real impact on these countries. Furthermore, books and magazines constituted the American "know-how" in print, an example of the modern civilization that through programs like Point IV was eager to spread its gospel around the less developed world. In fact, the publication and distribution of books and magazines was a fundamental expression of the Point IV purpose to promote the democratic-capitalist ideology and system as a model to be followed by less developed countries. Support for the modernization of those countries was not altruistic. Publishers like McGraw-Hill profited from selling the books and magazines. 
Despite the interest of companies like McGraw-Hill in the Point IV Program, the leading participant in its cultural cooperation was the Library of Congress. At the end of World War II, the Library of Congress continued its commitment to American librarianship in the development of libraries in other parts of the world. In this role, the Librarian of Congress, Luther Evans, on February 21, 1949, presented a confidential statement to Stephen P. Dorsey, a State Department official, about books and libraries on technical cooperation and assistance to be used as a plan for the Advisory Committee on Technical Assistance of the Point IV Program. Evans expressed:

We have never before lifted our eyes to the goal of transporting abroad a whole level of technological achievement. We can hope to achieve even a part of this noble aim only if we economize out of the technical personnel the utmost by employing to their fullest extent complementary means of conveying technical knowledge through publications and visual aids and only if we act to create abroad the basic resources for training local personnel to take over and extend what we shall have begun. It is in this broader concept of library activities as a component of all the phases of the technical assistance, rather than as a distinct phase in themselves that the attached memorandum has been submitted. (Evans, 1949)

For Evans, libraries and books needed to be seen as an integral part of technical cooperation and assistance. Consonant with the McGraw-Hill position, Evans argued that books and libraries were complementary in technical cooperation and assistance in that they had a long-term impact on the countries that received them. More importantly, Evans raised the key argument that with good libraries and books in situ, technical cooperation and assistance would save money. After an initial phase during which Americans provided knowledge and instruction, printed and audiovisual materials would be instrumental as permanent sources of "know-how" after the technicians left. Evans, like the McGraw-Hill executives, believed libraries and books should be an integral part not only of the Point IV Program, but also of the process of promoting the American democratic-capitalist ideology and system among less developed peoples.

Library activities also had important value as technical cooperation and assistance. Evans explained that American librarianship should play an important role in the promotion of improving library practices in that they would also foster modern democratic-capitalist sensibilities and practices. In his confidential statement, Evans requested technical cooperation and assistance in the library activities' part of the Point IV Program: 
These requests are all for assistance in enabling local libraries to offer more effective technical services. They fall into two major groups: those for assistance in developing improved library techniques and those for assistance in building up stronger and more useful collections in needed scientific and technical fields. (Evans, 1949)

Evans suggested that American librarianship ought to partake of the Point IV Program as the technical cooperation and assistance component of helping less developed countries improve their library techniques and build stronger collections. Many of the examples of possible technical assistance projects were in Latin America.

From the inception of the Point IV Program, the American Library Association's (ALA) leadership expressed solidarity with the Library of Congress' statement supporting the inclusion of library aspects in technical cooperation and assistance programs. In a memorandum entitled Present Status of Library Aspects of the Point IV Program, written in 1950, the ALA's International Relations Board supported the promotion of American librarianship in less-developed countries. (American Library Association, 1950) The Board understood the importance of improving the lives of peoples in those countries as something in the U.S. national interest. In an April 12, 1951 memorandum to John Mackenzie Cory, a State Department official, Dan Lacy, the ALA's Executive Secretary, proposed that the Association participate in the planning and execution of technical cooperation and assistance projects under the Point IV Program. (Lacy, 1951)

In the Point IV Program, international organizations like the United Nations Educational, Scientific and Cultural Organization (UNESCO) and the OAS were encouraged to cooperate as well. In a press release of the Department of State on June 29, 1951, the participation of the OAS in Point IV Programs was outlined. This organization cooperated with the Point IV Program promoted by the U.S. government, which got the OAS itself involved in technical cooperation and assistance. The library aspects included in the technical cooperation and assistance helped to improve many of the libraries in the region. (Department of State, 1951)

Since the First UNESCO General Conference in 1946, the international organization demonstrated itself to be a post-World War II leader in international librarianship. In his evaluation of UNESCO's first decade in library affairs, Verner Warner Clapp identified the following elements in which the organization had concentrated during those years (1946-56): 
$[\mathrm{P}]$ romotion of public library development; promotion of the development of bibliographic and documentation services and of research libraries and documentation centers; and promotion of the free flow and protection of library materials-exchanges, documentary reproduction, copyright, tariffs, books for blind, and protection of libraries in time of war. (Clapp, 1956: 2632)

In its Second General Conference in 1948, UNESCO supported comprehensive sets of recommendations and projects that in general called for a rapid development of librarianship worldwide as a vehicle for modernization and peace. Among them, the most important were the continuation of its championship of the book trade and of the exchange of publications. It will be considered the UNESCO Manifesto (UNESCO, 1949: 242-244) for libraries, book trade, and librarianship in general.

One of the more immediate results of this Manifesto was the creation of several public-library pilot projects used as examples of the implementation of these ideas, theories, and ideologies. Moreover, several international conferences were held in the spirit of the Manifesto. For some regions, like Latin America, these conferences provided a forum for the adoption of certain guidelines for the growth of regional librarianship.

For instance, in October 1951, UNESCO, the OAS, and the Brazilian government sponsored a Conference on the Development of Public Library Services in Latin America. Proceedings were held at the Municipal Public Library in Sâo Paulo, Brazil. Among the participants were 119 librarians from seventeen countries. The Sâo Paulo Conference was inspired on two key precedents: the UNESCO Manifesto and the 1947 Assembly of Librarians of the Americas. These two precedents prescribed a specific kind of public library development: the U.S. model.

It is important to scrutinize some of the work presented at the Sâo Paulo Conference to see the main lines of what later became the salient trend in the 1950s and 1960s in terms of Latin American public library, led by the OAS with the help of international organizations like UNESCO and the U.S. government. For Luis F. Málaga, librarian of the UN Economic Commission for Latin America, the objectives of public libraries were:

Public libraries will no longer remain warehouses for books or a refuge for unfortunate writers, but will be agencies for fundamental education collaborating in the work of teaching the ignorant masses. They will complement the education given in the schools and help to form the reading public of the future. They will act as social service agencies offering information, advice, recreation and guidance to children, adolescents and adults who do not come under the influence of formal education-regardless of social conditions, nationality, race, creed, language or 
profession. And finally they will be at the service of the interests of the community and of the highest human ideals, to awaken the social conscience of the individual and of the group, to contribute to the development of creative activities for the people and to guide and direct the altruism of the best elements of society.

The objectives of public libraries in Latin America are practically identical with those in other countries, but the same cannot be said of the problems to be met, nor of the methods to be followed. Public libraries, like schools, must adapt themselves in each country to particular physical and social circumstances. (Málaga, 1952: 22-23)

For this UNESCO official, the public libraries had "practically identical" objects in all countries, a generalization that was aired at the Sâo Paulo Conference and which later informed the pilot sponsored by UNESCO with OAS support. The problem with this notion of homogeneous function lay in how public libraries were to respond to their communities. In other words, how would public libraries with identical objectives function in different communities with a wide variety of socio-economic, political, and cultural development needs? The intention of UNESCO and the OAS to homogenize public libraries' objectives all around the world, and specifically in Latin America, is one element of what Tomlinson (1991) calls cultural imperialism.

Such public library modeling had the ideological repercussion of imposing a cultural model on societies that were quite different from the society which the model was based. In his paper at the Sâo Paulo Conference, Guillermo Nannetti (1952), Chief of Pam American Union's (PAU) Division of Education, proposed that using reading and visual materials in public libraries would influence people's minds in Latin America. With visual materials, public libraries would change people's behavior toward better citizenship. This argument is clearly reminiscent of the desires manifest by American elites in their historic advocacy of public libraries: reading would improve people's behavior and control social and moral misconduct. The ideological implications of the idea that through access to reading and visual material in public libraries one would create peaceful citizens in democratic-capitalist societies is fundamental to understanding the political intentions of the programs supported by UNESCO and the OAS in the post-War years.

In the Sâo Paulo paper presented by an official of a traveling library service sponsored by the National Confederation of Industry of Brazil, Nair Miranda Piraja (1952: 80-84) said that this program was a spontaneous initiative of the industrialists, who believed that education through books would promote better workers, and the nation's well-being. With peaceful workers and good 
citizens, industrialist demands would be met without class conflict. The paper revealed that some business organizations were sponsoring public libraries in Latin America, projects which UNESCO and OAS officials described as good examples. The public library role was not only to establish good, peace-loving citizens, but also to offset workers' demands and reduce class conflict.

Like Málaga's paper, Nannetti's and Miranda Piraja's papers revealed the ideological purpose of the Sâo Paulo Conference. UNESCO and the OAS wanted to establish public libraries to help transmit Western socio-economic, political, and cultural values to societies which lacked them. This ideological purpose represented a political position during the first years of the Cold War, according to which the democratic-capitalist system was favored over the communist one.

The most concrete result of the Sâo Paulo Conference was the resolution to establish a UNESCO's public library pilot project:

That UNESCO's projected Pilot Library be established as soon as possible, taking into account that some countries, such as Brazil (State of Paraná) and Guatemala have expressed their desire to become headquarters for that Pilot Library, and that Cuba and Colombia have also been mentioned as interested in the project. (UNESCO, 1952: 178)

UNESCO's intention was to promote library development and national planning through pilot projects. The Sâo Paulo Conference in general brought renewed impulse to Latin American public libraries. More importantly, it established the pattern that the OAS continued through the development of regional librarianship with the help of UNESCO.

UNESCO's assistance was of key significance, especially after the establishment of the Organization's Regional Office for the Western Hemisphere in Havana, Cuba, in 1951. Carlos Víctor Penna, an Argentine librarian trained in the U.S., was hired as a library specialist. A friend of the U.S. and a believer in American librarianship, Penna was a close collaborator of the OAS library development programs. It is important to more closely analyze UNESCO's impact on Latin American librarianship and libraries. For this analysis we must turn to the UNESCO public library pilot project in Medellín, Colombia.

The UNESCO Manifesto had an immediate impact on the development of the public library movement. The international cultural organization decided to establish public library pilot projects to show how the "modern" institution would run for the good of less-developed countries. These pilot projects conceptualized the establishment of public libraries as "modern" models for countries and societies, yet recognized 
the need for more experience in the manner that these kinds of institutions would be operated and managed.

One of the contradictions of the programs promoted by organizations such as UNESCO and the OAS is that they sold "modern" model institutions to countries that did not have the financial resources to sustain them. American public libraries were the results of not only particular cultural characteristics of the country but the level of wealth that the U.S. had attained as well. The greatest challenge of this pilot project fostered by UNESCO with OAS support was how, in a cultural environment different from the original, and in countries that enjoyed far less wealth than the U.S., the sponsors were going to develop this kind of institution. How, in a traditional society beset by poverty, could a "modern" institution be developed? This was the thorniest question that UNESCO and the OAS faced as they sponsored library development programs for Latin America. If institutions were results of their cultural, economic, social, and political environment, how could they thrive in different environments from those in which they were historically born? In their frenzy to quickly modernize the developing countries, international organizations like UNESCO and the OAS reversed the historical process and attempted to graft "modern" institutions onto nations that may have been ill-prepared for them. In many cases such intentions failed outright. The Medellín Public Library may be added to this list.

The Medellín Pilot Public Library was officially inaugurated on October 24, 1954, United Nations Day. The aim of this library was:

The Pilot Public Library for Latin America, at Medellín, was organized by the Government of Colombia, with UNESCO's help, as a pilot project to serve as a guide to public library development in Colombia and other Latin American countries. (Arroyave, 1957: 1)

As Julio Cesar Arroyave, the first Medellín Pilot Public Library's Director, explained, the government of Colombia and UNESCO supported that project not only for Colombia, but as a regional model of "modern" librarianship for all of Latin America. The Medellín Library also enjoyed the fu11 support of UNESCO's Director-General, Luther Evans who, selected the previous year as Director-General, ${ }^{1}$ was a believer in American librarianship as a "modern" model for Latin America and other less developed countries. As Librarian of Congress, Evans sponsored the Assembly of Librarians of 
the Americas in 1947, which produced the "blueprint" for the development of Latin American libraries along the lines that Evans preferred. With this "blueprint" and the UNESCO Manifesto in mind, Evans, through UNESCO, now turned his attention to a pilot project, a Latin American public library that would serve as an exemplar for others to imitate.

The OAS was an important collaborator in this and other similar pilot projects. From its earliest moments and through the 1950s, the Inter-American organization par excellence cooperated with this pilot project, which it hoped would serve as an example for other countries.

Immediately following the [inauguration] ceremonies, the Director of the Project, Dr. Julio César Arroyave, left for six-months study of libraries in the U.S. and agencies en route under the auspices of the Institute of International Education. [..] The Institute of International Education arranged with the to plan and direct his itinerary while in Washington. (Columbus Memorial Library, 1952)

It is significant that immediately after the facility's inauguration the Director of the Medellín Pilot Library traveled to the U.S. to see first-hand how the "modern" model" worked. It is also significant that the OAS organized Dr. Arroyave's itinerary in Washington, during which he visited important public libraries ${ }^{2}$ and analyzed their functions with the idea of applying them in Medellín. There is little question that since the establishment of the Medellín Pilot Public Library, the OAS collaborated with the project that intended to encourage the American public library as a "modern" model for Latin American library development.

Luther Evans (1954) argued that in the same year of the establishment of the Medellín Public Library, the pilot public library projects were, with intentions through "translation" to local realities, promoting the American public library as a "modern" model. But without the economic resources and sufficient support from civil society or the State, the UNESCO pilot projects could hardly "sell" the public library idea in less developed countries. "Demonstrations" and "experiments" were not the only way that the transfer of an institution like a public library could be successful; similar socio-cultural, economic, and political conditions needed to prevail in order for there to be even a small chance of fulfillment. The experience of the Medellín Pilot Public Library exemplifies this. ${ }^{3}$

2 Among the libraries visited by Dr. Arroyase in Washington, D.C. and vicinities were the Library of Congress, the Public Library of the District of Columbus (Main Library), Montgomery County Library in Maryland, and Enoch Pratt Free Public Library in Baltimore.

3 The other two pilot projects promoted by UNESCO were in Enugu, Nigeria (the Regional Central Library) in 1957, and Abidjan in Ivory Coast (the Ivory Coast Central Library). 
In 1958, UNESCO's Director-General requested a study on library needs in underdeveloped countries. The study looked at the needs of public libraries, and found them lacking in national library legislation, central public library agencies, local co-cooperation, trained personnel, adequate bibliographical tools, modern services and methods, better buildings and equipment, and library associations. Those needs were very similar to the ones identified by Arthur Eric Gropp (1952: 27-35) at the Sâo Paulo Conference and proposed as guidelines for Latin American library development in general. They were also similar to the areas that Marietta Daniels Shepard proposed for the Library Development Program in 1956. With similar ideas and diagnoses, these two organizations, UNESCO and the OAS, would continue collaborating during the 1950s and the 1960s.

From the OAS's inception in 1948, Columbus Memorial Library (CML) officials felt great pressure to reorganize in order to better adapt its services to the goals of this new organization. The CML pursued many of the activities performed years earlier by U.S. agencies, the ALA, and American foundations like the Rockefeller Foundation. The CML updated these activities to confront changing realities. But something that did not change was the old notion of using American librarianship as a "modern" model for the region. The following reflection by Marietta Daniels Shepard (1960: 2-3), the driving force behind the CML library development programs, is applicable to the entire span of CML programs in the 1950s:

In its expanded program for the improvement and extension of library and bibliographic services in America, the Pan American Union has endeavored to do the following: to collect, analyze, and disseminate information on the library movement in the America; to provide advisory and consultant services, as well as direct assistance, to member states, international agencies, and private organizations and institutions in their program of library development and related services; to promote the standardization and application of library and bibliographic techniques; to sponsor and participate in meetings devoted to the problems of the communication of information in the Hemisphere; to promote better professional relations among librarians through associations and cooperative efforts; to aid in the organization of libraries, in the teaching of library science, and in the application of effective research methods, through the preparation and publication of manuals, directories, bibliographies, and information pamphlets; and to help to stimulate easy access to printed materials through an improved inter-American booktrade and through the international exchange of publications between the governments and among institutions of the Hemisphere. The principal target of the program, however, has been the improvement and extension of the professional training of those who will be called upon to direct their countries' libraries, 
bibliographies services, and documentation centers, together with the production of the tools which they need both in their training and daily work. (Shepard, 1960: 2-3)

The activities of the CML on behalf of Latin American libraries and librarians, and of the exchanges between personnel and institutions of the two Americas, were ambitious. Most of them were meant to address the socio-cultural development of the Latin American region. The big question was: How did the activities that the CML promoted during the 1950s and later during the Alliance for Progress (1961-74), reflect the lessons learned from the experience and actions taken by American agencies in previous years? How were the American activities that served the CML as promoters learning experiences in terms of the success and failures of them?

As Marietta Daniels Shepard expressed, the principal target of CML activities and programs for Latin American librarianship development was the education and training of library workers. As in other ALA initiatives of the 1940s and early 1950s (e.g., the Assembly of Librarians in the Americas and its "blueprint" for Latin American librarianship development in 1947, and the Sâo Paulo Conference of 1951), the education and training of library workers in "modern" librarianship methods were deemed essential for regional advancement.

Other collaborative activities ensued between the OAS and UNESCO as a result of this conference and meeting. The Sâo Paulo Conference in 1951 about public library development is a good example of strong cooperation between these two organizations. The result of this meeting was the establishment of the Medellín Public Library Pilot Project. Other meetings in which the CML participated were sponsored by UNESCO, including the Expert Meeting of International Publications Exchange on Havana, Cuba in 1956. At this meeting, a series of ideas and standards to improve the exchange programs among nations were established; later the OAS tried to implement these ideas into its Library Development Program in the 1960s. These ideas pointed to the establishment of central agencies in nations to assist in the coordination of publications exchanges between countries. The establishment of central or national agencies for the development of such services had been supported by the ALA during the 1940s; the idea of modernizing the library practices in Latin American countries was fundamental to the OAS.

UNESCO, through its Office for the Western Hemisphere in Havana, Cu$\mathrm{ba}$, engaged in joint meetings with the OAS during the 1950s, to coordinate their work and avoid duplicity. The personal relationship and collaboration between Penna and Shepard would prove important for the development of 
Latin American libraries. Both believed that there was the possibility, through planning, for regional libraries to grow and develop following American librarianship as a "modern" model. They pursued this idea during the 1950s, and especially during the Alliance for Progress. The idea of planning as a way to develop Latin American libraries was, as will be seen, a key component of the Library Development Program established in 1956 by the CML, proposed by Shepard and supported by Penna.

The Library Development Program (LDP) resulted from a mandate of the Program of Cultural Action approved by the Second Meeting of the Inter-American Cultural Council in $1956 .{ }^{4}$ The LDP had wanted to confront the problems of Latin American libraries during the five years. It pretended to establish an ambitious program that would not only help in library development, but promote the exchange of publications, improve the acquisitions of materials throughout the hemisphere, foster translations, advance the standardization of library techniques, improve library education, and promote national associations of librarians. On top of all that, the program should also assist in the general cultural development of Latin American nations as well. Through a five-year plan, the LDP hoped to modernize Latin American libraries and several other aspects of regional librarianship.

The information that was presented to the LDP recognized that many of the initiatives were activities which were already in progress, had been suggested at Inter-American conferences and meetings, or comprised CML prerogatives. A deeper analysis of the LDP reveals that the program had other important historical precedents. It denoted influences from the ALA's initiatives in the 1940s, from the "blueprint" established at the Assembly of Librarians of the Americas, and from UNESCO initiatives of the 1940s and 1950s. From all these precedents and influences, the LDP followed the singular notion that American librarianship and library practices were "modern" models through which libraries and librarianship in the region would develop and modernize.

At the end of the 1950s, the CML had its LDP with the five-year plan approved, which served to confront the new challenges that were presented to the OAS, in general, and the Alliance for Progress. More important, at the end of the 1950s, UNESCO completely supported the LDP. In 1959, Penna called for a similar plan for Latin American library development, using many of the ideas and projects proposed in the LDP and its five-year plan as a base (Penna, 1959). At the end of the 1950s, the CML and OAS had the ideas and

4 The Inter-American Cultural Council was established by the OAS Charter in 1948. It was the specialized organism for cultural development of the OAS Council. 
plans to improve the standard of living and the cultural and educational level of the people of the Hemisphere through the development of libraries and other aspects of regional librarianship. They had the instruments already in place when the Alliance for Progress challenged them in the early 1960s.

\section{The Alliance for Progress and Its Library Initiatives}

On March 13, 1961, in a White House reception for Latin American diplomats and members of Congress, President Kennedy read the speech in which he launched the Alliance for Progress:

If we are to meet a problem so staggering in its dimensions, our approach must itself be equally bold, [...] Therefore I have called on all the people of the hemisphere to join in a new Alliance for Progress- Alianza para Progreso -a vast cooperative effort, unparalleled in magnitude and nobility of purpose, to satisfy the basic needs of the American people for homes, work and land, health, schools- techo, trabajo y tierra, salud y escuela. [...]

[...] I propose that the American Republics begin on a vast new 10-year plan for the Americas, a plan to transform the 1960's into an historic decade of democratic progress. These 10 years will be the years of maximum progress, maximum effort--the years when the greatest obstacle must be overcome, the years when the need for assistance will be the greatest.

[...]For if our alliance is to succeed, each Latin nation must formulate long-range plans for its own development--plans which establish targets and priorities, insure monetary stability, establish the machinery for vital social change, stimulate private activity and initiative, and provide for a maximum national effort. These plans will be the foundation of our development effort and the basis for the allocation of outside resources. (Kennedy, 1961-3-5)

To carry out this development, President Kennedy called for a ten-year plan that required a vast amount of resources from Latin American countries, the U.S., international organizations, and the private sector. The Alliance for Progress received formal approval at the Special Meeting of the Inter-American Economic and Social Council (IA-ECOSOC), a gathering at the Ministerial Level of the OAS from August 5 to 17, 1961, at which 
The IA-ECOSOC was the organism that President Kennedy called on to lead the formal establishment of the Alliance for Progress. ${ }^{5}$

That resemble of the Alliance for Progress also appeared in the continuation of cultural initiatives that they were part of the Point IV Program. As in the Point IV Program cultural initiatives were part of the Alliance for Progress to promote Latin American development in front of the Cold War ideological threats from communism. Specifically, something that help to reflect the continuity were the technical cooperation and assistance initiatives.

Technical cooperation and assistance programs during the Alliance for Progress combined the efforts of international organizations (such as the OAS and UNESCO), U.S. government agencies (such as the USAID and the Department of State), American universities, and American NGOs (such as the Ford Foundation, the Rockefeller Foundation, the Council on Library Resources and the ALA). The impact and extent of this cooperation and assistance were enormous, as Shepard explained:

The international commitments of universities in the United States have become a practical as well as an academic matter. [...] For Latin America alone some 60 [American] universities have entered into contracts with the Agency for International Development to assist [Latin American] universities in either their over-all development or in certain aspects, such as business administration or education, and others in research and training. (Shepard, 1968: 103)

Technical cooperation and assistance became an enterprise, as Brewster (1976) affirms, through which all these organizations wanted to assist the less developed nations. For many of these organizations, the 1960s was a decade of optimism, during which the possibility of developing those nations into "modern" societies became at last attainable, thanks to existing technology and knowledge. For USAID personnel, their commitment to the modernization and upgrade of less developed nations was a part of the idea that these countries would consequently support the capitalist system and reject communism.

The USAID was in charge of general policies during the Alliance for Progress, specifically the programs for technical cooperation and assistance in general. The second one was through a direct agreement that the government agency alone did (sometimes through a provider, for instance, ALA).

5 The U.S. government signed two formal agreements in which it gave the OAS funding to pursue its responsibility as the leader in the Alliance for Progress. The first, signed on November 29, 1961, was the Agreement between the Pan American Union and the Government of United States of America Concerning Certain Funds to be Made Available under the Alliance for Progress. The second was signed on December 4, 1962, and titled Grant Agreement between the Government of United States of America and the Pan American Union. 
The Alliance for Progress got a second push during at the Meeting of American Chiefs of State in 1967. Specifically with the enactment of a presidential National Policy and Statement on International Book and Library Activities the same year, USAID began a series of agreements with the ALA for the development of libraries and the promotion of book acquisitions in Latin America. As Brewster (1976) explained, the 1960s for ALA were the golden years in technical cooperation and assistance, mostly through its agreements with the USAID and with grants provided by the Rockefeller and Ford foundations and by the Council on Library Resources.

The USAID and the ALA carried out important technical cooperation and assistance in the area of library development during the Alliance for Progress. The university libraries received attention because as part of the Alliance for Program goals, development of these institutions would propel the rapid modernization of these nations.

These ideas to promote "know-how" and the "American-way" as a "model" were part of the Alliance for Progress also in other important cultural initiative, the promotion of books and printed materials. As part of the conception to establish permanent change in Latin American cultures, books and printed materials were fundamental for the Alliance. The idea to structural impact these countries with a "modern" cultural model were books and printed materials.

OAS officials continued working in developing projects for school and public libraries as well as participating in the program that was intended to eradicate illiteracy in the region. One of these projects was the Books for the Peoples Fund, Inc. Shepard explained what the Fund entailed:

The "Books for the People Fund," Inc., a private non-profit organization, was created in 1961 under the auspices of the OAS for the purpose of obtaining funds to finance the various projects necessary for complimenting the effort to raise the educational and cultural levels of a great number of the Latin American people, and to help their economic and social progress, as well as their scientific and technical development. It was created with the idea of stimulating the production and distribution of a large number of books, in Spanish and other languages spoken in the American continent, for children, youth and new adult literate; and to facilitate the cooperation and aid to this end of citizens, publishing houses, business groups, foundations, and government and international agencies in the American nations. The creation of the Fund is in accord with the convictions of both citizens of Latin America and the United States of the great scarcity of easy-to-read materials. (Shepard, 1971: 218)

The Books for the People project intended to help in the campaign of the 
Year Plan for Education. As Shepard argued, since the Alliance rapidly undertook its campaigns against illiteracy, the problem of lacking easy-to read books was felt acutely; without materials to read, the new literate adult would lose his or her learned techniques. In part to address this problems, and to create a core collection for school and public libraries, OAS officials established the Fund. A preliminary canon of children's literature and new adult literature (Listas de libros para niños y adultos recién alfabetizados recomendados para publicarse en español y portugués 1967) appeared as one of the first activities of the Fund. Many of these books were English books for children and the new adult literate population who wanted to be part of a translation program for Latin Americans. The Fund thus sought to stimulate American publishers and get some recommendations for original literature from Latin American authors.

The Fund likewise intended to stimulate the production of such literature in Latin America. In coordination with OAS' literacy programs, the Fund sought money to publish more of the pamphlet series produced by the OAS for the new literate adult called Biblioteca Popular Latinamericana (Latin American Popular Library). The Book for People harbored great intentions, similar to the ones that American elites possessed in the nineteenth century when they created the public library in the U.S. with the hope that through reading, the cultural and educational levels of the people would rise. It was an elitist vision that did not happen in the U.S. or Latin America; therefore, the Fund did not reach its primary goals. As Susan Shattuck Benson said: " $[t]$ he goals of the Books for the People Fund were broad and only partially reached..." (1992: 11) The principal reason why the Fund never really took off was that the American foundations never received the money necessary to start the mass production of books. Although it was technically a private non-profit organization, the Books for the People Fund always gave the impression of being an OAS project, and American foundations did not want to get money from international organizations that were understood to be political apparatuses, which did not have as their principal mission the education of the Latin American people.

Many American NGOs rejected the idea of even participating in the international advisory board of the Fund because of its relationship with the OAS. At the point of discredit during the Alliance for Progress, the OAS had already rejected the idea. Ironically, American institutions saw the OAS as a discredited institution, yet many of the actions that discredited the OAS followed U.S. policy.

Not all of the Books for the People Fund failed. As Benson (1992) asserts, Project LEER (Read) was a big success. For Shepard: 
Project LEER came into being as a new activity in the international book and educational fields with the formal signing on October 20, 1967, of an agreement to compile and make available lists of Spanish language books selected for public and school library purposes. The ultimate objective of Project LEER was announced to be that of assisting librarians in the United States and Latin America to procure the kinds of reading materials in Spanish they need for their actual and potential clientele. (Shepard, 1968: 108)

Although the primary target of Project LEER was the Spanish speaking population in the U.S., Shepard (1971) argued that Latin American library workers rapidly solicited these books and lists to develop their collection. Shepard explained that Project LEER concretized the reality of a growing Spanish-speaking population that needed services and did not want to lose its language. It is important to understand that Project LEER was born in the middle of the civil rights moment, when minority rights and minority cultures were being taken more and more into account by the educational systems (e.g., through bilingual education programs). Although Project LEER, like many educational and cultural programs during the nineteenth and early twentieth centuries, did not intend to assimilate Spanish-speaking children and erase the Spanish heritage, it had, as Harris (1973) and Williams (1988) claim the similar purposes of using reading to elevate the educational and cultural background of immigrant children. Through the canon created by elite librarians, these people pretended to determine what was good for the educational and cultural development of the Spanish-speaking population in the U.S. In the end, many libraries (school and public) in the United States and Mexico (primarily, although not exclusively) received Spanish books that bolstered many collections. Many American publishers benefited from the project with the production of these books for growing populations. ${ }^{6}$

The Books for the People Fund and Project LEER were very important initiatives for school and public libraries in Latin America and the U.S. Their conceptualization shared some key principles, especially the use of reading as a vehicle to increase the cultural and educational level of some targeted population. For these programs, the future of children, and of young and new adult literates in the whole hemisphere, was similar. These projects conceptualized the future of Latin America and the U.S. as similar; both would be "modern" societies with relatively well educated citizens.

6 The interest in Spanish education was so important for the OAS, that in 1972 the Reunion Interamericana de Expertos en Materiales de Enseñanza y Biblioteca en Español (Inter-American Meeting with Experts on Spanish Learning and Library Materials), was held from June 9-12, 1971. This Meeting took recommendations for teachers and librarians that dealt with Spanish speaking populations so Latin Americans and Americans were able to work together. 
They were manifestations of how deep the promotion of the American experience as a "modern" cultural model for Latin American societies.

One of the most interesting programs promoted by the USAID during the Alliance for Progress was the National Textbook Program and Libraries in Brazil. Part of the agreement between the USAID and the Brazilian government said:

In order to meet the educational needs of Brazil's growing school population by substantially increasing the free distribution of textbooks to the elementary and medium level schools and making available to the university students, an increasing number of textbooks at low cost, the President of the Republic established by Decree no. 59.355 dated October 4, 1966, the Textbook and Technical Book Commission (COLTED) in the Ministry of Education and Culture, with the responsibility of coordinating and implementing a textbook and technical book publishing program to make available approximately 51 million books within the next 3 years, through the existing publishing and distribution network, and of encouraging the strengthening and expansion of self-supporting, economically sound textbook and technical book publishing industry in Brazil, which, through market expansion, will reduce book costs. (Jackson, 1967: 23)

On November 10, 1966 the Minister of Education and Culture of Brazil and the USAID signed the agreement as part of the Alliance for Progress. William V. Jackson was the USAID consultant for that program. Jackson explained the program in this way:

Although the provision of free textbooks to every child and of low cost books to every university student in Brazil constitutes the primary objective of the National Textbook Program, improvement and expansion of libraries--especially those in schools and universities--stand high as a subsidiary goal of the project. (Jackson, 1967: 1)

Jackson went to Brazil to help in the implementation of the Textbook Program, which intended to establish a national publishing industry in Brazil at a low cost. In his report, Jackson indicated that he realized a national book industry could only be sustained with good libraries and with readers who regularly used those institutions. For that reason, he also recommended the establishment of a national plan. Although in his report he recommended the Textbook Program, the document appeared more as a "blueprint" for the "modernization" of Latin American countries. The Jackson report showed a tendency during the last years of the 1960s to see a more integrated library education, a national plan, technical cooperation, the promotion 
of libraries, and books--all as part of necessary steps toward reaching the goals of the Alliance for Progress, and toward accelerating the development of Latin American countries.

This "modernization" of Latin American countries was in many ways President John F. Kennedy vision. Although, the Alliance for Progress has many continuations from the Point IV Program as well as other American initiatives, the personal involve from the President of the United States rise the goals. The not completion of the Alliance for Progress created a great dissolution about the possibility to promote a "modern" cultural model to Latin America, the lost of the Alliance for Progress "historical leader" were basic for this failure. On November 22, 1963, the Alliance for Progress lost its "historic leader" when President Kennedy was assassinated.

As Lowenthal (1988: 217-220) says, with the death of President Kennedy, the Alliance for Progress lost much of the idealism it had first used to embark on its ambitious program of Latin American modernization. In his statement to an audience of Latin American representatives in Washington on November 26, 1963, entitled Let the Alliance Be His Living Memorial, President Lyndon Johnson (1963) reaffirmed his commitment to the goals. But, as Levinson and De Onís (1970) are quick to point out, under President Johnson the Alliance suffered because it was not his personal project.

Richard M. Nixon (1968) did not agree with the Alliance for Progress plans; he criticized the Alliance's lack of achievement and its poor record in stimulating development in Latin America. However, Nixon's approach was a top-down reaffirmed the idea of the big brother who needed to find the good path for the derailed brothers. With the lack of support for the Alliance (from the U.S. administration) in general and, specifically, with the continuing cuts in funds until only a few funds were available, the OAS General Assembly officially ended the Alliance for Progress on May 1, 1974. (The End of the Alliance, 1974)

\section{Conclusions}

Many of the initiatives undertaken and ideas tested in previous decades concerning cultural development culminated with the actions and programs taken on behalf of Latin Americans under the mantle of the Point IV and the Alliance for Progress. The activities carried out from the Point IV Policy to the Alliance for Progress bore the mark of an unfailing objective: to project the principles and procedures, the spirit and techniques of American librarianship onto the Latin American scene. An examination of 
these initiatives gives us a sense of the coherence of purpose implicit in a positivist conception of progress and modern civilization across the divide between Anglo-America and Iberian-America.

The challenge was how to translate that model into a different reality. It did not completely work there, and in failing to do so, it diminished the effectiveness of many initiatives carried out through the avenue of Inter-American relations. Another problem that surfaced was that U.S. government officials and international organization workers wanted to do things their way. Thus, the activities consummated through Inter-American relations had a major impact on Latin American cultural development; although in their implementation, there were problems that limited the scope of their influence.

However, in some instances American officials attempted to impose their criteria prompted resentment among Latin Americans. We may cite as exemplary how some Mexican cultural workers saw Marietta Daniels Shepard's initiatives through the OAS, according to Lester Asheim's confidential travel diary of 1962: "Marietta Daniels - imposes her ideas without any attempt to listen to local needs or interests; always runs the show; not always a show that makes sense here”. (Asheim, 1962: 182)

These insights may illustrate a broader problem concerning how the tone of the cultural development activities were not always well received in Latin American countries, particularly when U.S. government officials, and/or international workers seemed to be imposing their ideas without consulting the people in the region. Resentment also occurred sometimes, as in the case, when some educational activities were seen as American imposition and the students rejected such ideas as an act of cultural imperialism. Although in the majority of cases, American models were not the objects of any rejection, in a few cases there were accusations of cultural imperialism. In fact, American and International organizations actors intended to work in coordination with the support of national authorities, but the idea of exporting the American "model" to fit Latin America was an act of cultural imperialism. This is because the American culture and institutions were presented as superior "models" to Latin America.

American elites did not always harbor the same feelings about Latin America. After World War II, however, and because of these nations' failure to modernize in the way that American elites expected, frustration set in. The Cold War imposed the necessity of combating communism; for this reason, U.S. elites, while not abandoning the idea of "raising" or "improving" Latin American countries, did not embrace much hope for their future. 


\section{REFERENCES}

American Library Association. 1950. Present Status of Library Aspects of the Point IV Program, 1950, Memorandum. International Relations Board, American Library Association Archives. 7/1/6 Box 25.

Anslover, Nicole L. 2013. Harry S. Truman: the Coming of the Cold War, New York: Routledge.

Arroyave, Julio Cesar. 1957. Report on the Pilot Public Library for Latin America, Paris: UNESCO.

Asheim, Lester E. 1962. Travel Diary. American Library Association Archives. ALAA, 2/4/6, Box 18-2.

Benson, Susan Shattuck. 1992. "The Pioneers: Marietta Daniels Shepard." Third World Libraries 3: 9-13.

Brewster, Berverly J. 1976. American Overseas Library Technical Assistance, 19401970. Metuchen, New Jersey: The Scarecrow Press.

Clapp, Verner W. 1956. "UNESCO in Library Affairs-a Decade." Library Journal 81: 2631-2633.

Columbus Memorial Library. 1952. Report of the Librarian for the Month November 1954, Report, November. Organization of American States, Columbus Memorial Library. OAS-RC, CML RM, MNL B103 Ext. 8208, Box 2.

Department of State. 1951. Point Four Contracts for Economic Survey in Latin American Countries, Press Release. American Library Association Archives, June 29. $7 / 1 / 6$, Box 25 .

Evans, Luther H. 1949. Evans to Dorsey, Letter. American Library Association Archives, February 21. 7/1/6, Box 25.

Evans, Luther H. 1954. "UNESCO Work and Method Ilustrated by the Library Programs", in International Aspects of Librarianship: Papers Presented Before the Eighteenth Annual Conference of Graduate Library School of the University of Chicago, ed. Lean Carnovovsky, 12-30. Chicago: University of Chicago Press.

Gropp, Arthur E. 1952. "Inter-American Action Required." Development of Public Libraries in Latin America: The Sao Paolo Conference, 27-35. Paris: UNESCO.

Harris, Michael H. 1973. "The Purpose of the American Public Library: A Revisionist Interpretation of History." Library Journal (September): 2509-2514.

Jackson, William V. 1967. The National Textbook Program and Libraries in Brazil. Pittsburgh: University of Pittsburgh Book Center.

Johnson, Lyndon B. 1963. Let the Alliance be His Living Memorial. Washington, D.C.: Department of State.

Kennedy, John F. 1961. “Alianza para el Progreso.” Alliance for Progress. Washington, D. C.: Department of State.

Lacy, Dan. 1951. Lacy to Mackenzie, Letter. American Library Association Archives, April 12.7/1/6, Box 25.

Levinson, Jerome and Juan de Onís. 1970. The Alliance that Lost Its Way. Chicago: Quadrangle Books.

Lowenthal, Abraham F. 1988. "Kennedy's Vision Revisited.” The Alliance for Progress: a Retrospective, 217-220 New York: Preager.

Málaga, Luis F. 1952. "Needs and Objectives." Development of Public Libraries in Latin America: The Sao Paolo Conference, 21-26. Paris: UNESCO. 
McGraw-Hill International. N. d. Books and Magazines in the Point Four Program, American Library Association Archives. 7/1/6, Box 25.

Miranda Piraja, N. 1952. "The SESI Travelling Libraries.” Development of Public Libraries in Latin America: The Sao Paolo Conference, 80-84. Paris: UNESCO.

Nannetti, Guillermo. 1952. "The Problem of Providing Suitable Reading and Audio-Visual Materials." Development of Public Libraries in Latin America: The Sao Paolo Conference, 67-75. Paris: UNESCO.

Nixon, Richard M. 1968. For a Productive Alliance. Organization of American States, Columbus Memorial Library, October 15. CML-Vertical File, Alliance for Progress File.

Penna, Carlos Víctor. 1959. La Bibliotecología Latinoamericana: Algunas Consideraciones sobre el Pasado: Esbozo de un Plan para Acelerar su Desarrollo. La Habana: Anuario Bibliográfico.

Public Affairs Institute. 1951. Partners in Progress, Analysis of the Report, March. International Development Advisory Board, American Library Association Archives. 7/1/6. Box 25 .

Shepard, Marietta D. 1960. The Promotion of Libraries in the Americas: a Five Year Report of Activities of the OAS, Report, January 20. Organization of American States, Columbus Memorial Library. OAS-RC, CML RM, MNL B103, Box 2.

Shepard, Marietta D. 1968. "Progress Report on the Seminars on the Acquisition of Latin American Library Materials, 1967.” Final Report and Working Papers: Seminar on the Acquisition of Latin American Library Materials, XI, 91-148. Washington, D. C.: Organization of American States.

Shepard, Marietta D. 1971. "Progress Report on the Seminars on the Acquisition of Latin American Library Materials, 1970.” Final Report and Working Papers: Seminar on the Acquisition of Latin American Library Materials, XV, 79-223. Washington, D. C.: Organization of American States.

The End of the Alliance for Progress. 1974. México: CENCOS.

Tomlinson, John. 1991. Cultural Imperialism: A Critical Introduction. Baltimore: The Johns Hopkins University Press.

Truman, Harry S. 1979. "Inaugural Address." Public Papers of the President, Harry S. Truman, 1945-1953, 112-116. Millwood, New York: KTO.

UNESCO. 1949. "UNESCO Public Library Manifesto, The Public Library: a Force for Popular Education." UNESCO Bulletin for Libraries 3: 242-244.

UNESCO. 1952. "Development of Public Libraries in Latin America." Development of Public Libraries in Latin America: The Sao Paolo Conference, 178-188. Paris: UNESCO.

Williams, Patrick. 1988. The American Public Library and the Problem of Purpose, New York: Greenwood Press.

Para citar este texto:

Maymí-Sugrañes, Héctor J. 2017. “Cold Warriors: Advancing the Library Modernizing Model in Latin America”. Investigación Bibliotecológica: Archivonomia, Bibliotecología e Información 72 (31): 183-207. http://dx.doi.org/10.22201/iibi.0187358xp.2017.72.57829 